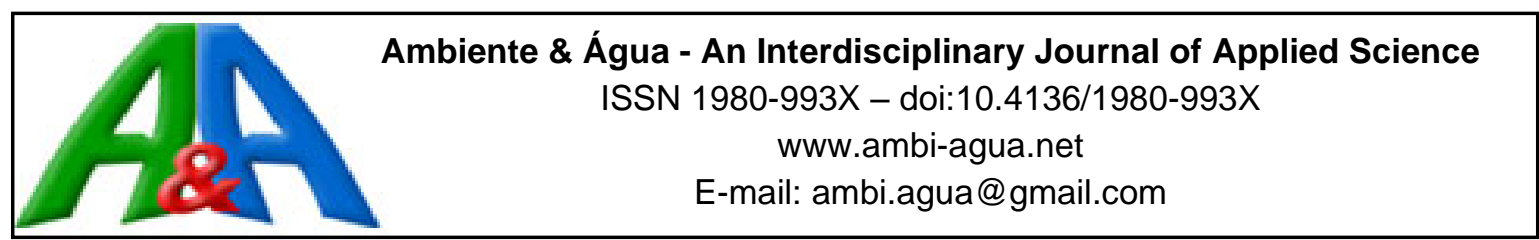

\title{
Statistical study of growth kinetics and lipid content of microalgae grown in brackish waters for bioenergetic purposes
}

\author{
ARTICLES doi:10.4136/ambi-agua.2649
}

Received: 15 Sep. 2020; Accepted: 19 Apr. 2021

\begin{abstract}
Bruna da Silveira Guimarães*iD; Kepler Borges França ${ }^{(i D}$
Unidade Acadêmica de Engenharia Química. Laboratório de Referência em Dessalinização (LABDES).

Universidade Federal de Campina Grande (UFCG), Rua Aprígio Veloso, nº 882, CEP: 58429-900, Campina Grande, PB, Brazil. E-mail: kepler123@gmail.com

*Corresponding author. E-mail: brunasilveiraguimaraes@hotmail.com
\end{abstract}

\begin{abstract}
This study aimed to statistically prove the influence of salinity on growth kinetics and intracellular lipid accumulation in microalgae. The species Chlorella sp., Scenedesmus acuminatus, Nannochloropsis sp., Monoraphidium contortum and Pediastrum tetras were studied, which were isolated in the Brazilian semi-arid region and cultivated in synthetic media with the addition of $\mathrm{NaCl}$. From the crops, growth kinetics, dry biomass production and lipid content were analyzed, using the experimental planning for one factor as a tool, with the $\mathrm{NaCl}$ concentration as an independent variable. The kinetic parameters maximum growth speed $\left(\mu_{\max }\right)$ and generation time $\left(\mathrm{t}_{\mathrm{g}}\right)$, as well as lipid concentration were the response variables studied. The results showed that, in the species Scenedesmus acuminatus, Nannochloropsis sp. and Pediastrum tetras, salt stress contributed to the increase in $\mu_{\max }$ and the consequent decrease in $\mathrm{tg}_{\mathrm{g}}$. The highest levels of lipid accumulation were obtained in Nannochloropsis sp. $(62.04 \%)$, in the medium with the highest salinity and Pediastrum tetras $(54.04 \%)$ in the lowest. Dry biomass production was higher in Scenedesmus acuminatus $\left(1,941.37 \mathrm{mg} . \mathrm{L}^{-1}\right)$ and Nannochloropsis sp. $\left(1237.05 \mathrm{mg} . \mathrm{L}^{-1}\right)$, both at a concentration of 4.0 g.L $\mathrm{L}^{-1}$. Therefore, saline stress acted directly on the cell growth and lipid content of the species, which can be used as a device to enhance lipid production for the purpose of producing biofuels.
\end{abstract}

Keywords: biofuels, biomass, biotechnology, brackish waters, lipids.

\section{Estudo estatístico da cinética de crescimento e teor de lipídeos de microalgas cultivadas águas salobras com fins bioenergéticos}

\section{RESUMO}

O presente trabalho teve como objetivo comprovar, estatisticamente, a influência da salinidade na cinética de crescimento e acumulação lipídica intracelular em microalgas. Foram estudadas as espécies Chlorella sp., Scenedesmus acuminatus, Nannochloropsis sp., Monoraphidium contortum e Pediastrum tetras, as quais foram isoladas na região semiárida nordestina brasileira e cultivadas em meios sintéticos com adição de $\mathrm{NaCl}$. A partir dos cultivos foram analisados a cinética de crescimento, produção de biomassa seca e teor de lipídeos, utilizando-se como ferramenta o planejamento experimental para um fator, tendo a concentração de $\mathrm{NaCl}$ como variável independente. Os parâmetros cinéticos velocidade máxima de crescimento $\left(\mu_{\text {máx }}\right)$ e tempo de geração $\left(t_{\mathrm{g}}\right)$, bem como concentração lipídica foram 
as variáveis resposta estudadas. Os resultados mostraram que, nas espécies Scenedesmus acuminatus, Nannochloropsis sp. e Pediastrum tetras, o estresse salino contribuiu para o aumento de $\mu_{\text {máx }}$ e consequente diminuição de $t_{\mathrm{g}}$. Os maiores níveis de acumulação lipídica foram obtidos na Nannochloropsis sp. $(62,04 \%)$, no meio com maior salinidade e Pediastrum tetras $(54,03 \%)$ no de menor. A produção de biomassa seca foi maior nas espécies Scenedesmus acuminatus (1.941,37 mg. $\left.\mathrm{L}^{-1}\right)$ e Nannochloropsis sp. (1237,05 mg. $\left.\mathrm{L}^{-1}\right)$, ambas na concentração de 4,0 g.L $\mathrm{L}^{-1}$. Portanto, o estresse salino atuou diretamente no crescimento celular e teor de lipídeos das espécies, podendo este ser utilizado como artifício para potencializar a produção lipídica, com fins de produção de biocombustíveis.

Palavras-chave: águas salobras, biocombustíveis, biomassa, biotecnologia, lipídeos.

\section{INTRODUCTION}

Since the middle of the twentieth century, it has been well known that rapid population growth and technological advances contribute to the increase in the planet's energy demand. According to studies, the tendency is that this demand will increase by up to $50 \%$ by 2030 . Fossil-fuel oil products cannot satisfy the current demand, as demand is 105 times greater than nature can replenish. It is well known that excessive dependence on fuels derived from petroleum causes great environmental damage in the medium- and long-term, including the reduction of fuel reserves, in addition to climate changes caused by the increase in the emission of gases such as $\mathrm{CO}_{2}$ (Shuba and Kifle, 2018).

The use of biofuels has been shown to be a viable alternative to solve dependence on petroleum derivatives, which can be produced from raw materials such as starch, vegetable oils, animal fats, biomass residues and algae biomass. As environmental benefits, biofuels reduce $\mathrm{CO}_{2}$, hydrocarbon and particulate matter emissions, in addition to eliminating emissions of SOx-type compounds, with a consequent reduction in greenhouse gases. The $\mathrm{CO}_{2}$ capture capacity of microalgae is between 10 and 50 times greater than many higher plants. Thus, greater photosynthetic efficiency is observed, in relation to higher plants, which is one of the positive points for use as a raw material for the production of biodiesel (Zhu et al., 2017).

Shuba and Kifle (2018) also point out that the productivity of biodiesel production from microalgae biomass can generally surpass the values of the best oil-producing crops. They also show that, compared to other crops, biomass has more potential for production, without negatively affecting the supply of food and other products of agricultural origin, since the crops can be grown on non-arable land, not used for agricultural purposes. Thus, there is no territorial competition with crops destined for food purposes.

Bellou et al. (2014) note that some species of microalgae are capable of accumulating considerable amounts of lipids, the main raw material for the production of biodiesel, being compared to higher oilseed plants. Zhao et al. (2021) show that saline stress is a device widely used and researched to maximize the synthesis of lipids in microalgae, since they are more viable processes, economically speaking. Qiao et al. (2021) also highlight that causing salt stress directly affects physiological and biochemical mechanisms linked to cell growth and consequent biomass production, causing ionic, osmotic and oxidative stress. Ionic and osmotic changes caused by salt stress reduce the activity of the $\mathrm{Na}^{+} / \mathrm{H}^{+}$ion, which impacts on photosynthetic activity. Thus, during lipid accumulation, the saline medium causes an increase in oxidative stress or accumulation of reactive oxygen species in the microalgal cells.

Zhang et al. (2017) still emphasize that the understanding of the regulatory mechanism for the production of lipids in microalgae cells is important in the development of technologies for the production of biofuels derived from microalgal biomass. Chew et al. (2018) show that recent research with the species Tetraselmis suecica and Nannochloropsis oculata shows the high 
potential for the production of biodiesel, being considered suitable species for large-scale production. Such research has also shown that some species, such as $T$. suecica, are able to grow in saline and brackish environments due to the presence of $\mathrm{Na}^{+}$pumps, which act on the osmoregulatory mechanism of cells, making them adaptable to rapid and gradual changes in salinity. Srivastava et al. (2017) found that the salinity of the medium contributes significantly in the synthesis of neutral lipids, more specifically the triacylglycerides (TAG) in the form of secondary metabolite, allowing the microalgal cells to support the increase in salinity. The exploitation of these factors can be of vital importance, implying the economic viability of the production of microalgae on a large scale for bioenergetic purposes. The author also points out that the salinity of the medium also interferes with the rate of respiration, assimilation of nutrients and carbon uptake.

Pancha et al. (2015) show that salt stress has been studied in the cultivation of species such as Chlamydomonas sp., Desmodesmus abundans and Nannochloropsis sp. In his work, the author studied the effect of salinity on the growth of freshwater microalgae Scenedesmus sp. The authors observed that saline stress caused physiological, biochemical and growth changes. Parameters were analyzed, such as biomass production, lipid content, carbohydrates, proteins, photosynthetic pigments, mineral contents, among others. The results showed an increase in lipid and carbohydrate levels in crops grown in a single phase, but with lower amounts of biomass.

Based on the literature review and the authors' knowledge, no studies were found to statistically prove the positive or negative influence of salinity on growth kinetics and on the content of microalgae intracellular lipids. Thus, the objective of this work is to prove, using experimental planning for one factor, the influence of the salinity of the medium in the cultivation of five species of microalgae, cultivated in brackish media, by the addition of $\mathrm{NaCl}$ in different concentrations. Based on the monitoring of growth in each medium and their comparison with the culture medium without the addition of this salt, the work analyzes which species increased cell growth, biomass production and lipid accumulation, thus proving the potential for the production of biodiesel.

\section{MATERIALS AND METHODS}

The study was carried out in a controlled environment at the Laboratório de Referência em Dessalinização (LABDES) located at the Universidade Federal de Campina Grande (UFCG) in Campina Grande, Paraíba, Brazil. Five strains of species were used, isolated in the semiarid region of northeastern Brazil. The species were: Chlorella sp., Scenedesmus acuminatus, Nannochloropsis sp., Monoraphidium contortum and Pediastrum tetras. Secenedesmus acuminatus, Monoraphidium contortum, Pediastrum tetras and Nannochloropsis sp. were replicated in synthetic Water Culture, recommended by Guillard and Lorenzen (1972). Chlorella sp. was replicated in Bold's Basal Medium synthetic medium, with a composition described by Bischoff and Bold (1963).

The methodology used for crops was developed by the authors. It was carried out from the inoculum in the synthetic media in photobioreactors (Figure 1), with a volume of 2 liters, adding $\mathrm{NaCl}$, in concentrations of $2.0 ; 4.0$ and $6.0 \mathrm{~g} . \mathrm{L}^{-1}$. In addition to these, the strains were also inoculated into the medium without the addition of salts, called Control for comparison between brackish media. The cultivation environment was controlled, with a temperature between 22.0 and $25.0^{\circ} \mathrm{C}$, based on Chisti (2008), who recommends a range between 20.0 and $30.0^{\circ} \mathrm{C}$ in the cultivation of microalgae. Light/dark photoperiod 12/12 h (384.0 lux) and constant aeration through micro pumps at a flow rate of $150.0 \mathrm{~L} \cdot \mathrm{h}^{-1}$ was used.

After this stage, cell growth was monitored solely by daily counting the number of cells per $\mathrm{mL}$, aiming at calculating the kinetic parameters based on the observance of the growth phases, as shown by Lee et al. (2015). The authors report that batch microalgal growth has six 
phases; lag, exponential or log, linear, of declining growth, stationary and of death. In addition, this process also had the purpose of visualizing viable and non-viable cells in each culture medium. Monitoring of $\mathrm{pH}$ also took place, aimed at observing changes in the media.

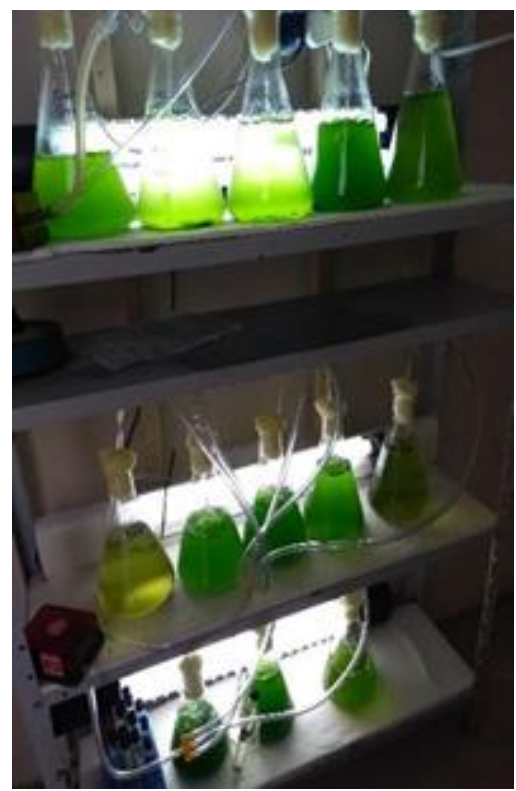

Figure 1. Photobioreactors in a controlled environment.

The counts were performed until the phase of stationary cell growth was reached, with the total cultivation time for Chlorella sp. between 10 and 13 days, between 15 and 18 days for Scenedesmus acuminatus and Nannochloropsis sp., for Monoraphidium contortum and Pediastrum tetras the cultivation time was 15 days. With the data obtained, the growth curves were plotted and the beginning and end of the exponential growth phase were observed for the kinetic calculations. After reaching the maximum number of cells, the biomass was separated by centrifuge and dried in an oven at $45.0^{\circ} \mathrm{C}$ to check the lipid content, according to the methodology recommended by Folch et al. (1957), modified for microalgae. However, the production of dry biomass per liter of cultivation was previously calculated by weighing.

From the kinetic results, a statistical study was made using the Hypothesis Test, from the experimental planning for one factor, testing the equality between means of the kinetic parameters of the treatments. This study was carried out through Test $\mathrm{F}(\alpha=0.05)$, applying analysis of variance (ANOVA) and Tukey's Test, aiming to know the influence of salinity (input variable) on the growth of species, comparing them the average values of the kinetic parameters of each medium with the Control. The levels varied according to the salinity of the media under study, that is, 0 (Control); 2.0 g.L. ${ }^{-1} ; 4.0$ g.L. $\mathrm{L}^{-1}$ and 6.0 g.L. ${ }^{-1}$. The response variables were the maximum growth speed $\left(\mu_{\max }\right.$, given day $\left.{ }^{-1}\right)$ and generation time $\left(\mathrm{t}_{\mathrm{g}}\right.$, given day), which depend on the cell concentrations obtained through the daily count. Such parameters are calculated from Equations 1 and 2, as discussed by Schmidell et al. (2001), where, $\mathrm{X}_{\mathrm{i}}$ is the cellular concentration (in cells. $\mathrm{mL}^{-1}$ ) at the beginning of the exponential phase and $\mathrm{X}$ is the final concentration, just as $t_{i}$ is the initial time of the exponential phase and the final time, in days. With this treatment, it was possible to compare the means of the kinetic parameters at the levels 2.0 g.L. $\mathrm{L}^{-1} ; 4.0$ g. $\mathrm{L}^{-1}$ and 6.0 g.L $\mathrm{L}^{-1}$ with the Control, observing which results showed significant differences.

$\ln \frac{X}{X_{i}}=\mu_{\max } \cdot\left(t-t_{i}\right)$ 
$\mu_{\text {máx }}=\frac{\ln 2}{t_{g}}=\frac{0,693}{t_{g}}$

\section{RESULTS AND DISCUSSION}

\subsection{Growth kinetics}

As shown in Figure 2, the $\mathrm{X}$ axis represents the $\mathrm{NaCl}$ concentration and the $\mathrm{Y}$ axis the kinetic parameters $\left(\mu_{\max }\right.$ and $\mathrm{t}_{\mathrm{g}}$ ). For Chlorella sp., the highest value of $\mu_{\max }$ and lowest $\mathrm{tg}_{\mathrm{g}}$ occurred in the Control and, among the brackish media; the best values were observed in the concentration of 4.0 g. $\mathrm{L}^{-1}$. In contrast, the Scenedesmus acuminatus species had better growth kinetics in the medium with higher salinity, reaching values much higher than that of the Control, which points to the fact that the cell growth of this species is favored in the media with higher salinities.

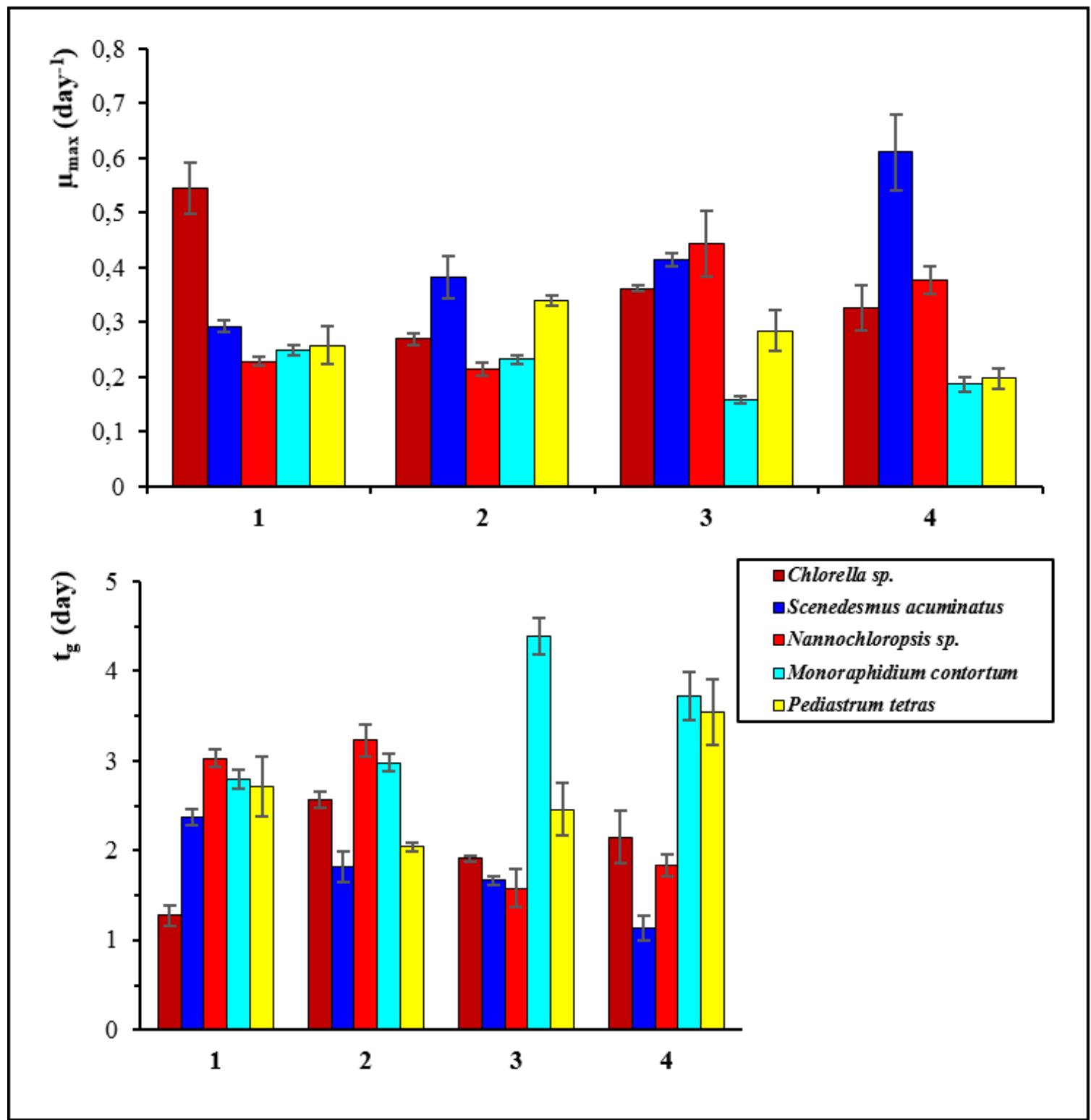

Figure 2. Maximum growth speed and generation time for all species in brackish and control environments.

The same occurred with Nannochloropsis sp., in which the values of $\mu_{\max }$ and $\operatorname{tg}_{\mathrm{g}}$ in the medium $4.0 \mathrm{~g} . \mathrm{L}^{-1}$ were more satisfactory than those of the Control. Similar results were not 
observed in the microalgae Monoraphidium contortum, where there were no major differences between the Control and the other concentrations. It appears that $\mu$ max and $\mathrm{t}_{\mathrm{g}}$, in brackish environments, did not exceed those of Control. For Pediastrum tetras species, the maximum growth speed and generation time were slightly higher in the media with salinity of 2.0 g.L. $\mathrm{L}^{-1}$ and 4.0 g. $\mathrm{L}^{-1}$, but without great increases in relation to the Control.

Comparing the species, the growth kinetics was favored in the media with higher salinities for Scenedesmus acuminatus and Nannochloropsis sp., and Chlorella sp., in this order. Nevertheless, it is observed in the latter that the kinetic results were not better than those of the Control. However, relating to Monoraphidium contortum and Pediastrum tetras, the results in concentrations of 4.0 and 6.0 g.L. ${ }^{-1}$ were more expressive for Chlorella sp.

Abubakar (2016) cultivated the microalgae Dunaliella sp., studying the ideal salinity in cell growth. The author shows that the growth rate was maximum in the medium with $\mathrm{NaCl}$ concentration of 1.0 Molar $\left(0.1680 \mathrm{day}^{-1}\right)$. This shows the great diversity of halotolerant species, that is, those that are able to adapt to brackish environments. The present study also shows this diversity, to the extent that species with greater adaptability were used, since they were obtained, mainly in the cultivation of Chlorella sp., Scenedesmus acuminatus and Nannochloropsis sp., higher rates of maximum growth and generation time in media with higher salinities.

\subsection{Statistical analysis of growth kinetics}

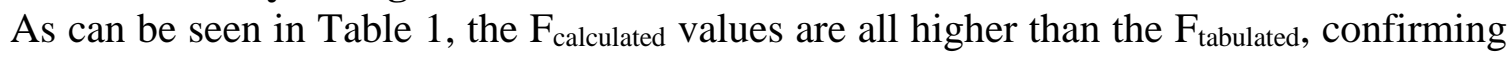
the significant difference between the means.

Table 1. F test for $\mu_{\max }$ and $\mathrm{t}_{\mathrm{g}}$ with $\alpha=0.05$. $\left(\mathrm{F}_{\text {tabulated }}=4.07\right)$.

\begin{tabular}{ccccc}
\hline & $\mathrm{F}_{\text {calculate }}\left(\mu_{\max }\right)$ & $\mathrm{F}_{\text {calculate }}\left(\mathrm{t}_{\mathrm{g}}\right)$ & $\mathrm{R}^{2}\left(\mu_{\max }\right)$ & $\mathrm{R}^{2}\left(\mathrm{t}_{\mathrm{g}}\right)$ \\
\hline Chlorella sp. & 42.25 & 32.37 & 94.06 & 92.39 \\
Scenedesmus acuminatus & 32.88 & 50.52 & 92.50 & 94.99 \\
Nannochloropsis $\mathrm{sp}$. & 34.62 & 80.71 & 92.85 & 96.80 \\
Monoraphidium contortum & 54.90 & 48.84 & 95.37 & 94.82 \\
Pediastrum tetras & 14.54 & 14.47 & 84.51 & 84.33 \\
\hline
\end{tabular}

It can be seen in Figure 3 that the test is approached graphically through the comparison between pairs of means. The $\mathrm{X}$ axis represents the difference between them and the $\mathrm{Y}$ axis all possible combinations between the culture media, performed by the Tukey Test. For the present study, the following were observed: Control-2.0 g.L $\mathrm{L}^{-1}$, Control-4.0 g.L $\mathrm{L}^{-1}$ and Control-6.0 g.L $\mathrm{L}^{-1}$, both with respect to $\mu_{\max }$ and $\mathrm{t}_{\mathrm{g}}$. For Chlorella sp. (1) between the pair Control and $2.0 \mathrm{~g} . \mathrm{L}^{-1}$ medium, the greatest significant difference occurred. As the interval is to the right of zero, the salt concentration is therefore influencing the value of $\mu_{\max }$ in order to decrease this parameter, which confirms the results obtained in Figure 2.

In Scenedesmus acuminatus (2), the biggest significant difference was between the Control and 6.0 g. $\mathrm{L}^{-1}$ media. The range is further away from the zero on the left, indicating that the salinity at the 6.0 g.L. $\mathrm{L}^{-1}$ level is influencing in order to increase the value of $\mu_{\text {max. }}$ This result is confirmed by the fact that the maximum growth speed in the Control was the lowest value observed among the crops. For Nannochloropsis sp. (3) there was no significant difference between the Control and the concentration of $2.0 \mathrm{~g} . \mathrm{L}^{-1}$. A greater influence of salinity can be observed in the medium with 4.0 g.L $\mathrm{L}^{-1}$, followed by $6.0 \mathrm{~g} . \mathrm{L}^{-1}$, with both influences of salinity 
being positive. These results confirm what was shown in Figure 1, where the highest values of $\mu_{\max }$ occurred in these concentrations.

For Monoraphidium contortum (4), there was a greater influence of salinity in the concentration of 4.0 g.L $\mathrm{L}^{-1}$ in order to decrease $\mu_{\max }$. Thus, this species does not have favored kinetics in brackish environments. It is also noticed that there was a significant difference between the Control and the concentration of 6.0 g.L. $\mathrm{L}^{-1}$, without influence of salinity at the level 2.0 g.L. $\mathrm{L}^{-1}$ at maximum speed. The test for Pediastrum tetras (5) showed a significant difference in 2.0 g.L. $\mathrm{L}^{-1}$ media, being positively influenced by the salt concentration. In the other concentrations, salinity did not statistically affect the average value of the maximum growth speed.

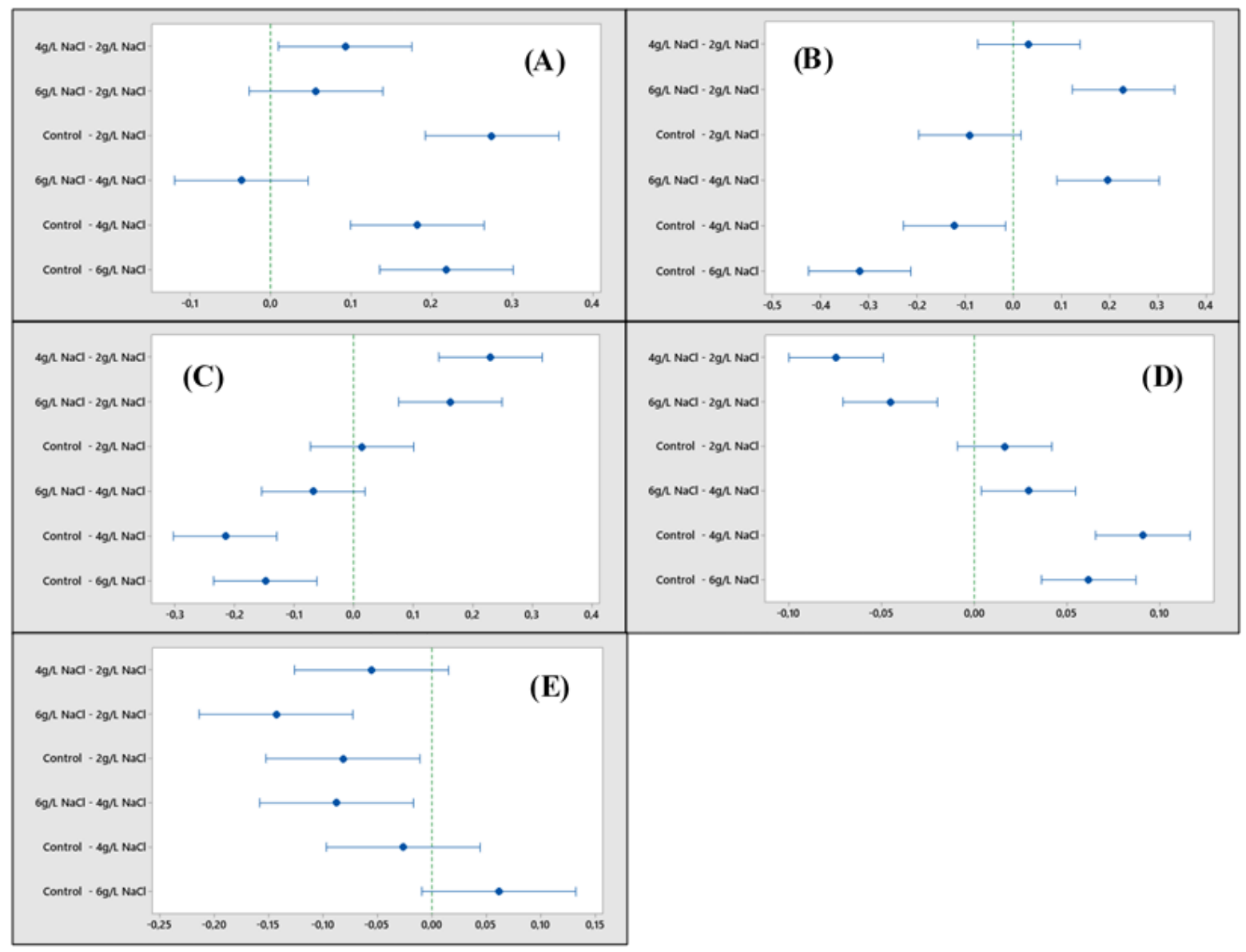

Figure 3. Tukey test between the averages of the maximum velocity of growth in synthetic brackish media. A. Chlorella sp., B. Scenedesmus acuminatus, C. Nannochloropsis sp., D. Monoraphidium contortum, E. Pediastrum tetras.

Looking at Figure 4, Chlorella sp. (1) showed a significant difference in all concentrations compared to the Control, with the greatest influence observed in that of $2.0 \mathrm{~g} . \mathrm{L}^{-1}$. It also occurred in all medium pairs for Scenedesmus acuminatus (2), but the highest was between Control and the medium with the highest salinity. For Nannochloropsis sp. (3), there was a greater difference with the concentrations of 4.0 g.L. $\mathrm{L}^{-1}$ and 6.0 g.L. $\mathrm{L}^{-1}$, but salinity was more influential in the first. The same happened with the species Monoraphidium contortum (4), with a greater influence of $\mathrm{t}_{\mathrm{g}}$ for medium with a concentration of $4.0 \mathrm{~g} . \mathrm{L}^{-1}$ of $\mathrm{NaCl}$. In Pediastrum tetras (5) cultures, there were significant differences between the Control and the concentrations of 2.0 g. $\mathrm{L}^{-1}$ and 4.0 g.L $\mathrm{L}^{-1}$, with no impact on salinity. Therefore, the species that proved to be more suitable for cultivation in brackish environments are Chlorella sp., Scenedesmus acuminatus and Nannocholopsis sp. 


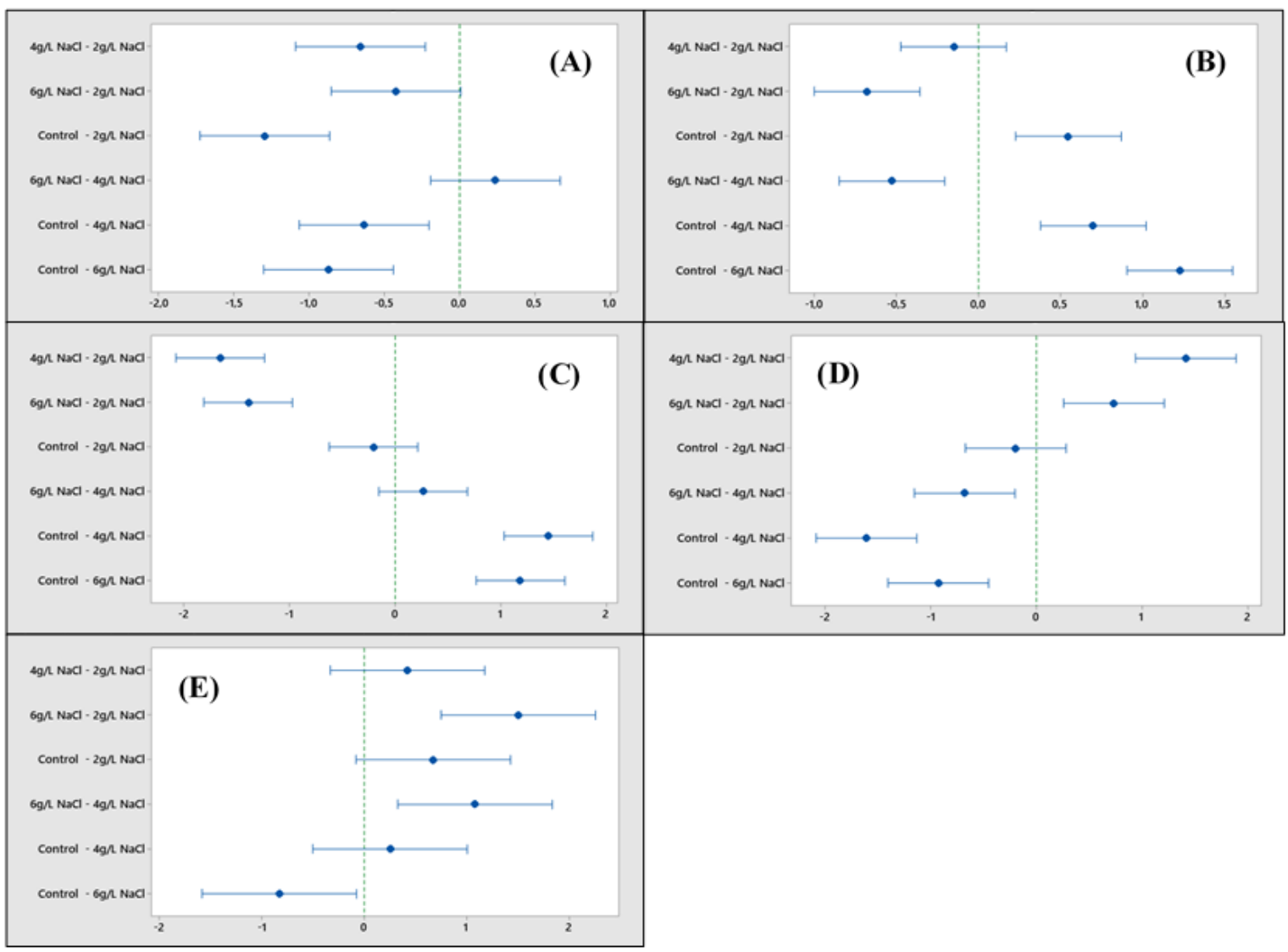

Figure 4. Tukey test between the generation time averages in the synthetic brackish media. A. Chlorella sp., B. Scenedesmus acuminatus, C. Nannochloropsis sp., D. Monoraphidium contortum, E. Pediastrum tetras.

\subsection{Lipid content and biomass production}

Figure 5 reveals that Chlorella sp. was the species that presented the lowest values of the lipid content, if compared with the others. Shuba and Kifle (2018) show that the levels of lipids for this species in standard culture media can vary between 14 and $22 \%$. In the present study, values close to $10 \%$ were obtained among brackish media, the highest observed in the concentration 4.0 g.L $\mathrm{L}^{-1}$ of $\mathrm{NaCl}(11.69 \%)$.

Chlorella sp. had the highest biomass production in Control $\left(621.90 \mathrm{mg} . \mathrm{L}^{-1}\right)$, followed by the concentration of 4.0 g. $\mathrm{L}^{-1}\left(559.65 \mathrm{mg} . \mathrm{L}^{-1}\right)$, highest production among brackish media, 2.0 $\mathrm{gL}^{-1}$ (428.90 mg. $\mathrm{L}^{-1}$ ) and the highest salinity (342.60 mg.L $\left.{ }^{-1}\right)$. However, in all media in which salt was added, the lipid percentage did not increase compared to the Control. Regarding the Scenedesmus acuminatus, the results show that the highest lipid accumulation among brackish media occurred at $6.0 \mathrm{~g} . \mathrm{L}^{-1}$, which is the medium that came closest to the Control. This result points to the fact that cultivation in media with higher salinity can favor the accumulation of lipids, caused by the salt stress in the cells. The highest biomass production occurred at a concentration of $4.0 \mathrm{~g} . \mathrm{L}^{-1}$, surpassing the Control.

Pancha et al. (2015) cultivated the species Scenedesmus sp. in brackish media and obtained a lipid percentage of $33.13 \%$ at a saline concentration of $400 \mathrm{mM}$, this being the highest studied. In the present study, the lipid content was higher $(41.96 \%)$ in the culture with greater addition of salts, showing that the intracellular lipid production can be favored in higher salinities. This fact was also verified in the species Nannochloropsis sp., where the highest content of lipids in dry biomass also occurred in the medium with a concentration of $6.0 \mathrm{~g} . \mathrm{L}^{-1}$, reaching the highest result among the studied species. Therefore, for this microalgae the highest salinities have also maximized the accumulation. 


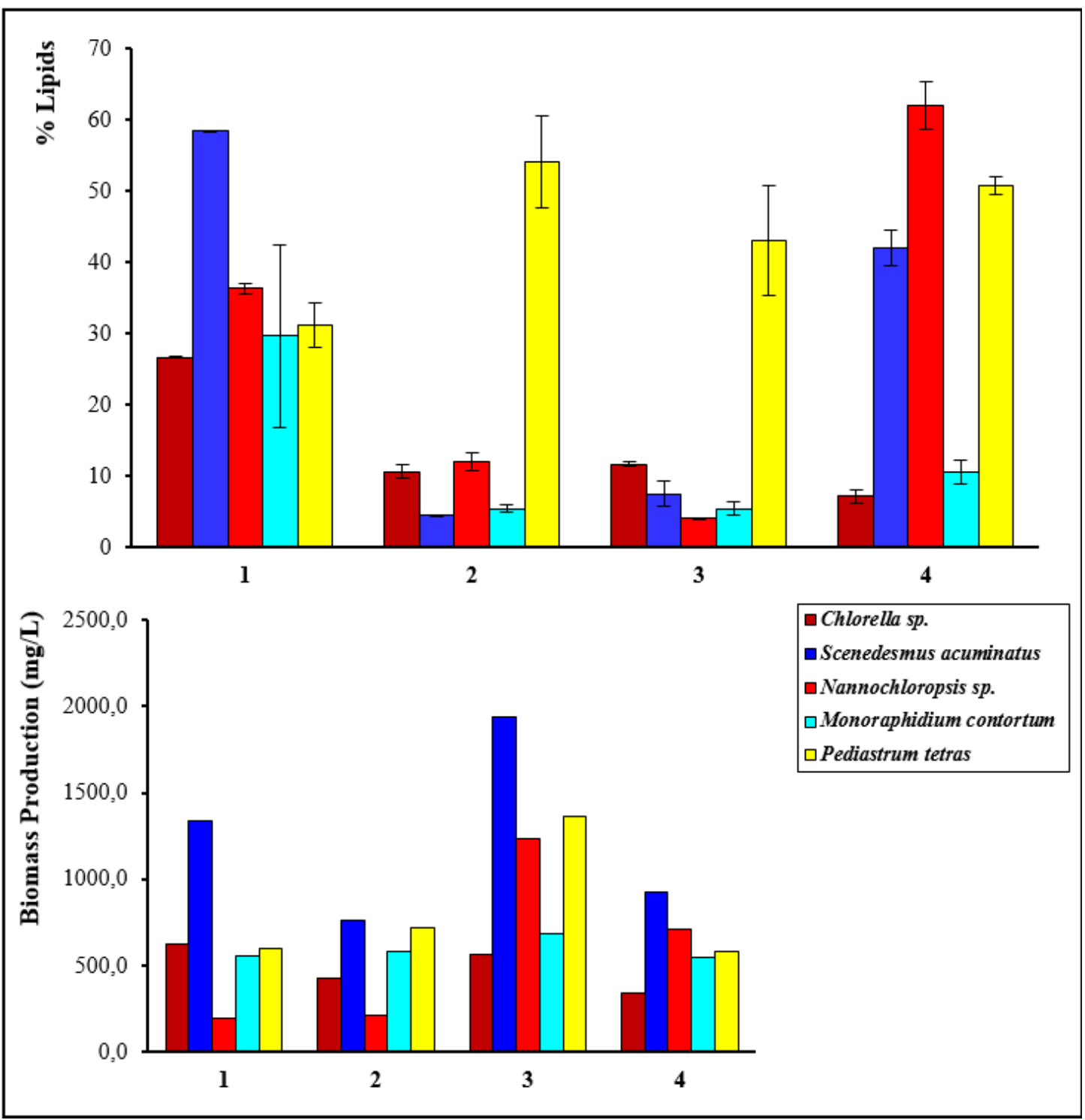

Figure 5. A. Percentage of the concentration of lipids and B. Production in dry biomass of brackish media.

According to Khatoon et al. (2014), Nannochloropsis sp. is among the microalgae with the highest lipid concentrations, remaining between 20 and $50 \%$ of dry biomass. In the present study, production was higher $(62.04 \%)$, showing that the highest salt concentration provided this expressive result. The authors also point out that the acceptable levels of salinity vary with the species, and each has an optimal range for growth and lipid production. Kalita et al. (2011) point out that saline stress has a direct impact on physiological and biochemical mechanisms directly related to cell growth. For this reason, cultivation in brackish environments can increase the lipid content and the production of biomass.

On the other hand, the lowest results between species occurred in Monoraphidium contortum, where the highest lipid level did not exceed $10.57 \%$ in the 6.0 g.L. $\mathrm{L}^{-1}$ concentration of $\mathrm{NaCl}$ and the highest productivity was for the $4.0 \mathrm{~g} . \mathrm{L}^{-1}$ concentration $\left(684.61 \mathrm{mg} . \mathrm{L}^{-1}\right)$. Meanwhile, Bogen et al. (2013), when cultivating this same species in a synthetic medium to evaluate the lipid content and productivity in dry biomass, obtained the values of $22.2 \%$ of lipid accumulation; however, with $300 \mathrm{mg} . \mathrm{L}^{-1}$ of biomass production. Therefore, the cultivation of this species in brackish environments can increase the production of biomass, but no increase in lipid accumulation is observed. The Pediastrum tetras species showed a very satisfactory percentage of lipids, and it was observed that in all brackish environments there was an increase 
in relation to the Control. The highest value was observed in the concentration of $2.0 \mathrm{~g} . \mathrm{L}^{-1}$, reaching $54.03 \%$. However, the study authors note that this species is not widely studied and cultivated, and there are no relevant works to be mentioned.

Concerning the production in dry biomass, no significant increases were observed with salinity in relation to the Control for Chlorella sp. as for Monoraphidium contortum. It is verified that the salt levels did not cause a significant increase in the production of biomass. Scenedesmus acuminatus, Nannochloropsis sp. and Pediastrum tetras, however, showed a considerable increase in the concentration of $4.0 \mathrm{~g} . \mathrm{L}^{-1}$, and it was verified that this salinity potentiated the production of biomass.

Observing the results and, relating growth kinetics, lipid accumulation and dry biomass production, it appears that the species that were most favorable to be cultivated in synthetic brackish media were Scenedesmus acuminatus and Nannochloropsis sp. It is observed that in the first, the medium with 6.0 g.L $\mathrm{L}^{-1}$ had the best combination of results, showing that the production of biomass and lipid content are favored in the medium with greater salinity, in addition to the kinetic aspects. For the second species, the brackish medium was also shown to be the most suitable for cultivation, because despite having a lower biomass production and slightly slower growth kinetics, it was in this medium that the lipid production was maximum.

\subsection{Statistical analysis of lipid content}

Table 2 shows that for all cultures there was a significant difference between the mean results of lipid percentage.

Table 2. $\mathrm{F}$ test for the $\%$ of Lipids in cultures in brackish media $\left(\mathrm{F}_{\text {tabulated }}=4.07\right)$.

\begin{tabular}{ccc}
\hline & $\mathrm{F}_{\text {calculate }}$ & $\mathrm{R}^{2}$ \\
\hline Chlorella sp. & 519.83 & 99.49 \\
Scenedesmus acuminatus & 347.12 & 99.78 \\
Nannochloropsis sp. & 619.65 & 99.57 \\
Monoraphidium contortum & 9.56 & 78.19 \\
Pediastrum tetras & 7.31 & 84.54 \\
\hline
\end{tabular}

From Figure 6, it can be seen that in the brackish cultivations of Chlorella sp. (1) there was a significant difference between the Control and all means. Due to the fact that the intervals are to the right of zero, it can be seen that salinity is affected in a way to decrease lipid accumulation, having a greater impact on the medium with a concentration of 6.0 g.L. ${ }^{-1}$. The same occurred with Scenedesmus acuminatus (2) and Monoraphidium contortum (4), with the greatest influence observed in media with a concentration of 2.0 and 4.0 g.L. $\mathrm{L}^{-1}$, respectively. Note that in Nannochloropsis sp. (3), the medium with 6.0 g. $\mathrm{L}^{-1}$ salinity increased the percentage of lipids, since the interval is to the left of zero. In the other media, salinity affected lipid accumulation in order to decrease it, which points to the increase in the percentage of lipids from cultures grown in salinity media for this species. Pediastrum tetras showed only a significant difference between the Control and the 2.0 g.L.-1 media, which was positive.

Kaewkannetra et al. (2012) studied the effect of salinity in cultures of the microalgae Scenedesmus obliquus in the presence of $\mathrm{NaCl}$, in concentrations of $0.05,0.2$ and $0.3 \mathrm{M}$. Compared with the non-brackish medium, the highest lipid accumulation was obtained in the cells that grew under salt stress, obtaining a 36.0\% lipid content. Duan et al. (2012) used the same strategy for the species Chlorella vulgaris, through the osmotic stress caused by the salinity. The author reports that he obtained a $21.1 \%$ increase in lipids compared to nonbrackish medium. It also shows that higher concentrations of salt increased the content of lipids to $70 \%$ in the cultivation of Dunaliella. Xia et al. (2014) tested several sodium salts to cause an 
increase in the lipid content, with $\mathrm{NaCl}$ increasing the productivity of Desmodesmus abundans to $68.08 \mathrm{mg} . \mathrm{L}^{-1} \cdot \mathrm{dia}^{-1}$. The author points out that the increase in salinity is a simple mechanism to promote cell growth for the production of biomass for bioenergetic purposes.

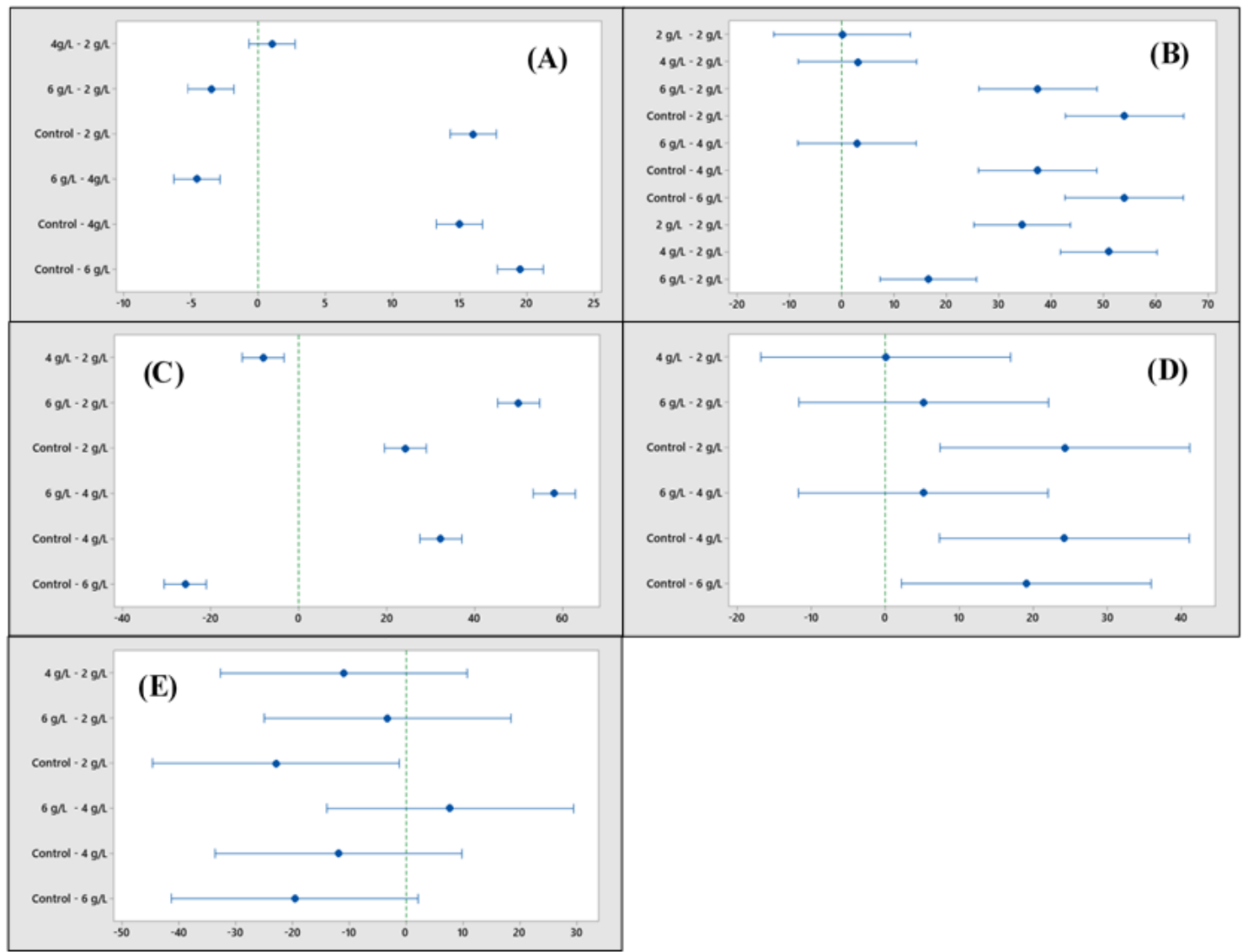

Figure 6. Tukey test for \% lipids in synthetic brackish cultures. A. Chlorella sp., B. Scenedesmus acuminatus, C. Nannochloropsis sp., D. Monraphidium contortum, E. Pediastrum tetras.

The present study obtained a higher percentage of lipid accumulation for the microalgae Scenedesmus acuminatus, when compared with the work by Kaewkannetra et al. (2012). It is also observed that for Nannochloropsis sp. and Pediastrum tetras, the values also exceeded those of the author. This fact indicates the feasibility of using several species of microalgae in the production of biomass for the purpose of producing biodiesel. As a differential, this study highlights the use of the statistical tool to prove the influence of salinity on the growth kinetics and production of lipids. It appears that, in all the studied species, there was an interference of salinity in the physiological cellular mechanisms that, depending on the concentration of the salt and the species, increased or decreased the growth and lipid production.

\subsection{Monitoring the $\mathbf{p H}$}

It can be seen in Figure 7 that in all crops there was an increase in $\mathrm{pH}$ over time. Dahmani et al. (2016) show that this fact is directly linked to photosynthetic activity, where the $\mathrm{CO}_{2}$ in the medium is consumed by the cells, thus decreasing the concentration and consequently increasing the $\mathrm{pH}$ of the medium. The authors also point out that the optimal range for most microalgae species is between 7.0 and 12.0. For Scenedesmus acuminatus, Nannochloropsis sp., Monoraphidium contortum and Pediastrum tetras (grown in Water Culture synthetic medium) the $\mathrm{pH}$ has always been alkaline, in the range specified by the authors. It is noticed that, on the day of the inoculum, the $\mathrm{pH}$ was between 9.0 and 10.0 and then dropped to 7.0 on the first day. From the fifth day on, it increased again, to between 8.0 and 10.0. 


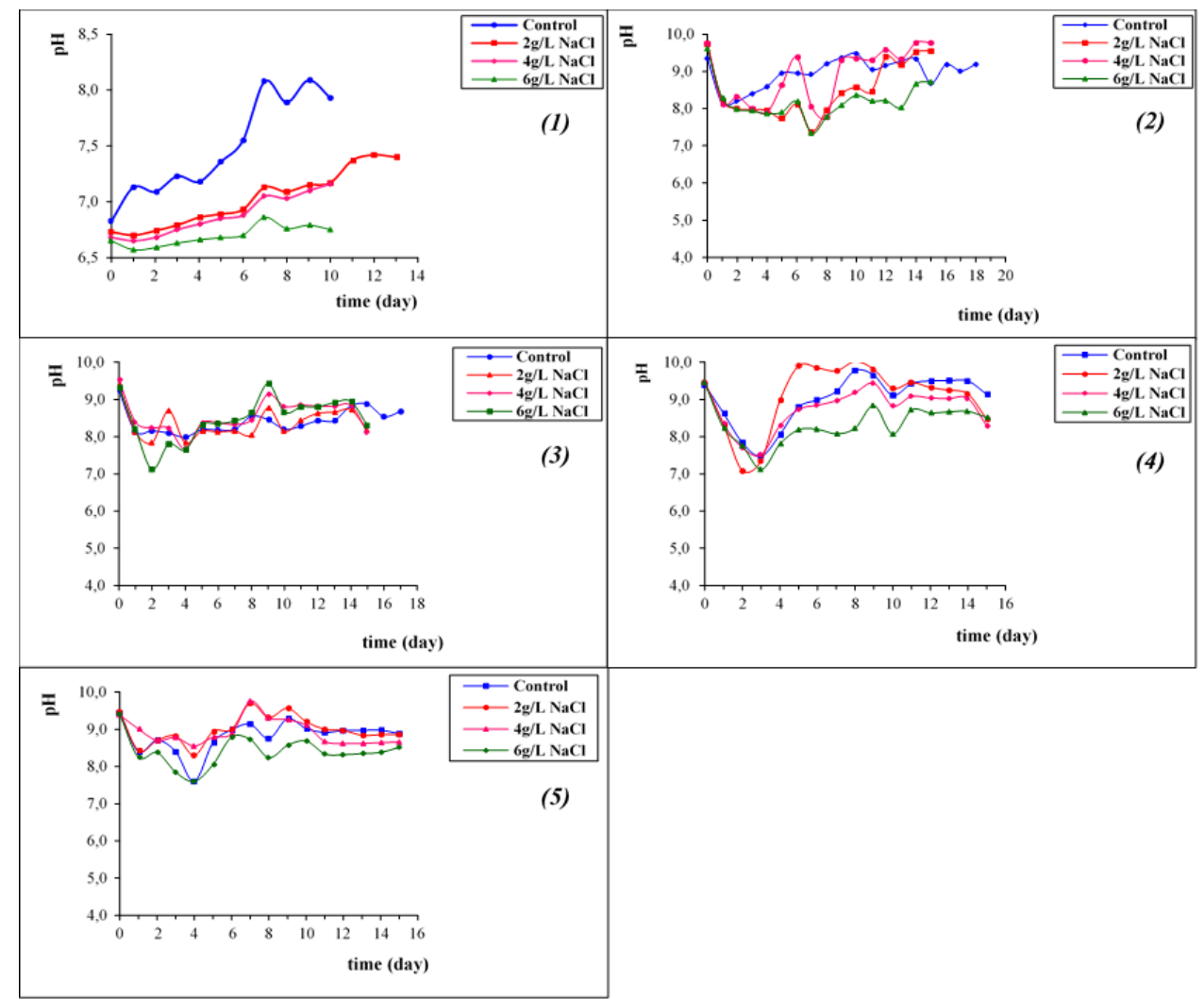

Figure 7. $\mathrm{pH}$ of synthetic brackish media over the time of cultivation. (1) Chlorella sp., (2) Scenedesmus acuminatus, (3) Nannochloropsis sp., (4) Monoraphidium contortum, (5) Pediastrum tetras.

Chlorella sp. showed that $\mathrm{pH}$ of the synthetic culture medium (Bold's Basal Medium) on the day of the inoculum was close to neutral. During the cell growth there was an increase, however, among the brackish media $\mathrm{pH}$ did not exceed 7.5 and the Control reached $\mathrm{pH}$ 8.0. Thus, the influence of both $\mathrm{pH}$ and salinity on the low production of biomass and lipids for this species can be seen.

\section{CONCLUSIONS}

The study found the influence of saline stress on growth, production of dry biomass and accumulation of lipids in all species. It is observed that among them Scenedesmus acuminatus and Nannochloropsis sp. were the ones that most adapted to the brackish environment. It has been proven that, depending on the species, the concentration can positively or negatively influence the growth kinetics and accumulation of lipids. In the species Scenedesmus acumnatus and Nannochloropsis sp., the growth was benefited by the salinity in the concentrations 6.0 and 4.0 g.L $\mathrm{L}^{-1}$, respectively. Regarding lipids, Nannochloropsis sp. and Pediastrum tetras had the accumulation maximized with the concentration in 6.0 and 2.0 g.L $\mathrm{L}^{-1}$, respectively.

The species that reached the highest levels of lipids were Nannohchloropsis sp., Pediastrum tetras and Scenedesmus acuminatus, as well as showing the highest production of dry biomass, both at concentrations of 4.0 g.L $\mathrm{L}^{-1}$. The results confirm the feasibility of using microalgae as an alternative for the production of biodiesel. The lipid content and the amount of biomass produced become crucial in the choice of the species to be cultivated. It is worth mentioning that it is necessary to observe these two factors together in order to obtain the highest possible yield for the production of biofuel. 


\section{ACKNOWLEDGMENT}

The authors would like to thank the Coordenação de Aperfeiçoamento de Pessoal de Nível Superior (CAPES) for their financial support.

\section{REFERENCES}

ABUBAKAR, A. L. Effect of Salinity on the Growth Parameters of Halotolerant Microalgae, Dunaliella spp. Nigerian Journal of Basic and Applied Science, v. 24, n. 2, p. 85-91, 2016. https://doi.org/10.4314/njbas.v24i2.12

BELLOU, S.; BAESHEN, M.; ELAZZAZY, A. M.; AGGELI, D.; SAYEGH, F. Microalgal lipids biochemistry and biotechnological perspectives. Bioresource Technology, v. 288, 2014. https://dx.doi.org/10.1016/j.biotechadv.2014.10.003

BISCHOFF, H. W; BOLD, H. C. Some Soil Algae from Enchanted Rock and Related Algal Specie. Austin: University of Texas, 1963. (Phycological Studies IV, n. 6318). p. 1-95.

BOGEN, C.; KLASSEN, V.; WICHMANN, J.; LA RUSSA, M.; DOEBBE, A.; GRUNDMANN, M.; URONEN, P.; KRUSE, O.; MUSSGNUG, J. H. Bioresource Technology Identification of Monoraphidium contortum as a promising species for liquid biofuel production. Bioresource Technology, v. 133, p. 622-626, 2013. https://dx.doi.org/10.1016/j.biortech.2013.01.164

CHEW, K. W.; CHIA, S. R.; SHOW, P. L.; YAP, Y. J.; LING, T. C.; CHANG, J. S. Effects of water culture medium, cultivation systems and growth modes for microalgae cultivation: A review. Journal of the Taiwan Institute of Chemical Engineers, v. 0, p. 1-13, 2018. https://dx.doi.org/10.1016/j.jtice.2018.05.039

CHISTI, Y. Biodiesel from microalgae beats bioethanol. Trends in Biotechnolo gy, v. 26, n. 3, p. 126-131, 2008. https://dx.doi.org/10.1016/j.tibtech.2007.12.002

DAHMANI, S.; ZERROUKI, D.; RAMANNA, L.; RAWAT, I.; BUX, F. Cultivation of Chlorella pyrenoidosa in outdoor open raceway pond using domestic wastewater as medium in arid desert region. Bioresource Technology, v. 219, p. 749-752, 2016. https://dx.doi.org/10.1016/j.biortech.2016.08.019

DUAN, X.; REN, G. Y.; LIU. L. L.; ZHU W. X.; Salt-induced osmotic stress for lipid overproduction in batch culture of Chlorella vulgaris. African Journal of Biotechnology, v. 11, p. 7072-7078, 2012. https://dx.doi.org/10.5897/AJB11.3670

FOLCH, J.; LESS, M.; STALEY, G. H. A Simple Method for the Isolation and Purification of Total Lipids from Animal Tissues. The Journal of Biological Chemistry, v. 226, p. $497-$ 509, 1957.

GUILLARD, R. R. L.; LORENZEN, C. J. Yelow-green algae with chlorophyllide. Journal Phycology, v. 8, p. 10-14, 1972. https://doi.org/10.1111/j.1529-8817.1972.tb03995.x

KAEWKANNETRA, P.; ENMAK, P.; CHIU, T. The Effect of $\mathrm{CO}_{2}$ and Salinity on the Cultivation of Scenedesmus obliquus for Biodiesel Production. Biotechnology and Bioprocess Engineering, v. 17, p. 591-597, 2012. https://doi.org/10.1007/s12257-011-05335

KALITA, N.; BARUAH, G.; GOSWAMI, R. C. D.; TALUKDAR, J.; KALITA, M. C. Ankistrodesmus falcatus: A promising candidate for lipid production, its biochemical analysis and strategies to enhance lipid productivity. Journal of Microbiology and Biotechnology Research, v. 1, p. 148-157, 2011. 
KHATOON, H.; RAHMAN, N. A.; BANERJEE, S.; HARUN, N.; SULEIMAN, S. S.; ZAKARIA, N. H.; LANANAN, F.; HAMID, S. H. A.; ENDUT, A. International Biodeterioration \& Biodegradation Effects of different salinities and $\mathrm{pH}$ on the growth and proximate composition of Nannochloropsis sp. and Tetraselmis sp . isolated from South China Sea cultured under control and natural conditions. International $\begin{array}{lllllll}\text { Biodeterioration } \quad \text { B } & \text { Biodegradation, } & \text { v. } & 95, & \text { p. } & 11-18,\end{array}$ https://doi.org/10.1016/j.ibiod.2014.06.022

LEE, E.; JALALIZADEH, M.; ZHANG, Q. Growth kinetic models for microalgae cultivation: A review. Algal Research, v. 12, p. 497-512, 2015. https://dx.doi.org/10.1016/j.algal.2015.10.004

PANCHA, I.; CHOKSHI, K.; MAURYA, R.; TRIVEDI, K.; PATIDAR, S. K.; GHOSH, A.; MISHRA, S. Salinity induced oxidative stress enhanced biofuel production potential of microalgae Scenedesmus sp. CCNM 1077. Bioresource Technology, v. 189, p. 341-348, 2015. https://dx.doi.org/10.1016/j.biortech.2015.04.017

QIAO, T.; ZHAO, Y.; ZHONG, D.; YU, X. Hydrogen peroxide and salinity stress act synergistically to enhance lipids production in microalga by regulating reactive oxygen species and calcium. Algal Research, v. 53, Article 102017, 2021. https://dx.doi.org/10.1016/j.algal.2020.102017

SCHMIDELL, W.; BORZANI, W.; LIMA, U. A.; AQUARONE, E. Biotecnologia Industrial, Volume 2. $1^{\text {a }}$ ed. São Paulo: Editora Blucher, 2001. 560 p.

SHUBA, E. S.; KIFLE, D. Microalgae to biofuels: 'Promising' alternative and renewable energy, review. Renewable and Sustainable Energy Reviews, v. 81, n. April 2016, p. 743-755, 2018. https://dx.doi.org/10.1016/j.rser.2017.08.042

SRIVASTAVA, G.; NISHCHAL; GOUD, V. V. Salinity induced lipid production in microalgae and cluster analysis (ICCB 16-BR_047). Bioresource Technology, v. 242, p. 244-252, 2017. https://dx.doi.org/10.1016./j.biortech.2017.03.175

XIA, L.; RONG J.; YANG, H.; HE, Q.; ZHANG, D.; HU, C. NaCl as an effective inducer for lipid accumulation in fresh water microalgae Desmodesmus abundans. Bioresource Technology, v. 161, p. 402-409, 2014. https://dx.doi.org/10.1016/j.biortech.2014.03.063

ZHANG, X.; TANG, X.; WANG, M.; ZHANG, W.; ZHOU, B.; WANG, Y. J. ROS and calcium signaling mediated pathways involved in stress responses of the marine microalgae Dunaliella salinato enhanced UV-B radiation. Journal of Photochemistry

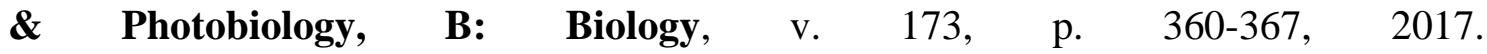
https://dx.doi.org/10.1016/j.jphotobiol.2017.05.038

ZHAO, Y.; SONG, X.; ZHAO, P.; LI, T.; XU, J.; YU, X. Role of melatonin in regulation of lipid accumulation, autophagy and salinity-induced oxidative stress in microalga Monoraphidium sp. QLY-1. Algal Research, v. 54, p. 1-9, 2021. https://dx.doi.org/10.1016/j.algal.2021.102196

ZHU, B.; CHEN, G.; CAO, X.; WEI, D. Molecular characterization of $\mathrm{CO}_{2}$ sequestration and assimilation in microalgae and its biotechnological applications. Bioresource $\begin{array}{lllll}\text { Technology, } & \text { v. } & 244, & \text { p. } & 1207-1215,\end{array}$ https://dx.doi.org/10.1016/j.biortech.2017.05.199 